\title{
The conservation reserve system in the South Coast Region of NSW looks impressive, but does it adequately conserve threatened plant species?
}

\author{
Kevin Mills \\ 12 Hyam Place, Jamberoo, NSW 2533. \\ Email:k.mills@bigpond.net.au
}

\begin{abstract}
The listed threatened plant taxa within the South Coast Region of New South Wales (Helensburgh to Batemans Bay, as designated by the NSW National Parks and Wildlife Service) are documented. Of the 100 NSW listed taxa, 69 are also listed by the Commonwealth, while two additional taxa are only listed by the Commonwealth. An analysis of the individual taxa and the 62 conservation reserves in the region, found that 30 taxa can with confidence be said to be adequately reserved, while 50 are assessed as inadequately reserved; for the remaining 22 taxa, reservation status is unknown.

Examples of challenges for the conservation of threatened plants in the region are examined; these challenges have relevance well beyond the South Coast Region. Managing for individual plant species may be hampered by a lack of basic ecological information; this is particularly so for the rarer species such as orchids. One of the main areas where information is lacking is the response of most species to bushfire. Conservation on private land is becoming an increasingly important and challenging area for plant species conservation as the last large areas of public land are dedicated for one purpose or another. A more co-ordinated approach to conservation on private land may produce improved outcomes for many inadequately reserved taxa.
\end{abstract}

Cunninghamia (2012) 12(4): 325-337

doi: 10.7751/cunninghamia.2012.12.023

\section{Introduction}

During the past 15 years conservation areas on the NSW South Coast Region (as defined by the NSW National Parks and Wildlife Service - NPWS) have been greatly increased; these reservations have brought the area under NPWS management to 25 percent of the Region. There is a further 6,312 hectares in the Commonwealth Booderee National Park. This high proportion of conservation land reflects the fact that historically, a large part of the Region has remained undeveloped and unfarmed because of the poor soils associated with its extensive sandstone landscapes; it is at the southern end of the very extensive Sydney Basin geological province. Because the poor soils and rugged landscapes were of little value for agriculture, the majority of the sandstone country remained in public ownership with its native vegetation relatively undisturbed and suitable for subsequent reservation as conservation lands. This scenario is characteristic of most of the reserves in the Sydney Basin including much of the land which makes up the Greater Blue Mountains World Heritage Area for example. A consequence of this phenomenon is that the vast majority of the protected areas in the South Coast region are located on sandstone soils, and that sandstone landscapes and their characteristic vegetation are over-represented within the conservation reserve system. In contrast the more fertile country, with 
its substantially different suite of vegetation, is mostly in freehold ownership, much of it has been cleared and is poorly represented in reserves.

Land managed by NSW Forests covers a large part of the south-eastern part of the Region, and while much of that land is managed for wood production, conservation needs are considered in forestry operations. Forestry land, and other public land, is not investigated in this paper but this does not discount the importance of some of that land for the conservation of threatened plants.

With 62 reserves covering over 354,500 hectares, the reserve system in the South Coast Region looks impressive, but does it adequately conserve the threatened plant species occurring within the Region? This paper provides a contemporary review of the currently listed threatened plant species occurring in the Region and their conservation status. Challenges for the conservation of threatened plants in the Region are explored using first hand examples from the South Coast; these challenges are by no means unique to the South Coast Region.

\section{The South Coast Region}

The South Coast Region, as considered in this paper, extends from Helensburgh in the north (just south of the metropolitan area of Sydney), to Batemans Bay in the south, and westwards to beyond Goulburn and the vicinity of Braidwood. The Region covers an area of 1.4 million hectares. Altitude ranges from sea level to over 1,100 metres on the peaks within Budawang National Park in the southwest corner of the region. Geology is highly variable. Sedimentary rocks of Permian and Triassic age within the Sydney Basin geological province cover the majority of the region, with extensive areas of Permian volcanic rocks (latite and volcanic sandstone) in the far northeast. The region overlaps the southern and south-western extremities of the Sydney Basin, so that on the tablelands in the west old sedimentary rocks of Ordovician and Devonian age occur with occasional igneous rocks. Tertiary basalt occurs in a few places, mainly at high altitudes. Annual average rainfall ranges from around $600 \mathrm{~mm}$ in the dry, western parts of the region to over $1,800 \mathrm{~mm}$ per year along the high escarpment in the far north.

Botanically, the Region overlaps the Central Coast, South Coast, Central Tablelands, and Southern Tablelands Botanical Subdivisions (PlantNET online, National Herbarium of NSW, Sydney). The Bio-Regions involved are the Sydney Basin, South-East Corner and South Eastern Highlands (NSW NPWS 2003). The Region primarily supports forests and woodlands, with extensive areas of heathland on sandstone landscapes (Mills \& Jakeman 2010).

Broadly speaking, the region can be divided into three distinct areas; viz. (i) the coast and its hinterland, primarily supporting moist forests, (ii) the sandstone plateaux, supporting woodland and heathland and (iii) the tablelands, where modified woodlands and grasslands dominate, with forests in the wetter north-eastern corner on the Central Tablelands.
The total area covered by NPWS reserves in the Region is 348,192 hectares, contained within 61 protected areas. Parks Australia, a Commonwealth authority, manages Booderee National Park in the Jervis Bay Territory; that reserve covers 6,312 hectares. There are also two marine parks managed by Marine Parks Authority NSW. The terrestrial reserves represent over 25 percent of the total land area in the Region. These reserves range from three hectares in Belowla Island Nature Reserve to Morton National Park that covers 199,744 hectares; the latter park, one of the largest in NSW, represents $57 \%$ of the total reserved land in the Region. Of approximately 280 kilometres of coastline, 36 percent is managed by the NPWS or Parks Australia (Mills 2006).

Sixteen of the reserves $(26 \%)$ are less than 100 hectares in area; this includes five oceanic island reserves. All protected areas in the Region are listed in Table 4, where the area of each reserve and other information is provided.

\section{Methods}

Records of threatened plant species were sought from various places, most particularly:

- The Atlas of NSW Wildlife, maintained by the Office of Environment and Heritage (OEH), containing 4,192 records of threatened plant species within the South Coast Region;

- Threatened species information on the OEH web site;

- Information from staff and the library at the NPWS office in Nowra;

- Plans of management for the protected areas;

- The author's knowledge and library of information on the flora of the region.

All threatened taxa records in the Region were assessed to identify the occurrence of taxa within protected areas; all obviously erroneous records were excluded and outdated taxonomy corrected. Information on population numbers was more difficult to obtain, as detailed field surveys are lacking for the majority of species. Statements about reservation status were only made where firm population information was available.

Each species is assessed for 'reservation adequacy'. The assessment, determined by the author and made largely on a subjective basis, with some quantitative information for some species, indicates the adequacy or otherwise of each species within the reserve system of the NSW NPWS South Coast Region. The terms used are: adequate - substantial populations occur within one or more protected areas or all/almost all known populations occur in protected areas; inadequate - substantial populations do not occur in a protected area or most known populations are outside the reserve system, although small numbers may be reserved; and unknown - the adequacy of reservation could not be determined because of a lack of information. 
Table 1. Number of Listed Plant Taxa in the South Coast Region TSC Act EPBC Act $\quad$ EPBC only

$\begin{array}{llllll}\text { extinct } & 1 & 1 \% & 1 & 1 \% & - \\ \text { critically endangered } & 4 & 4 \% & 2 & 3 \% & - \\ \text { endangered } & 50 & 50 \% & 24 & 35 \% & 1 \\ \text { vulnerable } & 45 & 45 \% & 42 & 61 \% & 1 \\ \text { All listed species } & 100 & 100 \% & 69 & 100 \% & 2\end{array}$

Table 2. Growth Habit of Listed Taxa

(Note. Figures are also the approximate percentage)
Usual growth habit

Tree

Mallee

Shrub

Vine

Forb

Grass

Sedge

Orchid

Fern

All species

\section{Number}

6

3

54

1

15

2

16

3

102
Table 3. General habitat showing number of Listed taxa (Note. Figures are also the approximate percentage)

\section{General Habitat Category}

Rainforest/moist eucalypt forest

Forest

Woodland/heathland (sandstone)

Swamps (sandstone)

Woodland/scrub (tablelands)

Grassy woodland/grassland

Upland peat swamps

Estuarine wetlands/sandy beaches

\section{Number}

10

24

32

5

14

6

6

5

\section{The Threatened Species in the South Coast Region}

Threatened plant taxa in NSW as listed under the Threatened Species Conservation Act 1995 are continually being added to through determinations made by the NSW Scientific Committee (as provided for under the Act). Species can also be listed under the Fisheries Management Act 1994, although no plant species have yet been listed for the Region under that Act. As of March 2012, 637 plant taxa are listed as threatened in NSW; 100 (15.6\%) occur within the South Coast Region, which covers $1.7 \%$ of the state.

The threatened plant taxa occurring within the South Coast Region are summarised in Table 5. The table provides information on plant families, taxonomic and common names for each taxon, their status under the above act and in the South Coast Region, the regional protected area(s) in which the taxon is known to occur, habitat, growth habit and reservation status as determined in this paper. Those taxa listed under the Commonwealth Environment Protection and Biodiversity Conservation Act 1999 (EPBC Act) are identified and their status indicated. Two species are listed only by the Commonwealth; these species are included in this analysis.

\section{Status}

102 plant taxa occurring in the Region are listed as extinct, critically endangered, endangered or vulnerable under the TSC Act and/or the EPBC Act (Table 1).

As far as is known, there is only one plant species that has apparently become extinct in this region; this is the orchid Arachnorchis cadyi (Caladenia cadyi); see Stephenson (2011). This species is not listed as extinct under either the TSC Act or EPBC Act, even though there is provision to list species that are presumed extinct. The taxon Amperea xiphoclada var. pedicellata is listed under both acts as extinct, although there have been recent records from several parts of the Region (Atlas of NSW Wildlife, March 2012). Of the 102 species listed for the region, $69(69 \%)$ are listed under the Commonwealth EPBC Act.

\section{Endemism and limit of distribution}

Regional endemism is high; $33 \%$ of the listed species occur nowhere else except the South Coast Region, or have almost all of their known populations within this region. Endemism is particularly high among the orchids; nine of the 16 listed species are found only in the Region.

The number of taxa at their southern limit of geographic distribution is also high, 39\%; the number of taxa at their northern limit in the Region is lower at $14 \%$. A total of $86 \%$ of all listed taxa are either endemic or at their limit of distribution, demonstrating the high importance of the region for plant conservation. The high percentage of "southern limit species" is partly explained by the fact that the Region overlaps the southern edge of the Sydney Basin; there is a major change in the flora to the south of the Basin, from just north of Batemans Bay.

\section{Growth habit}

The listed species range from small herbs to large trees (Table 2). Growth habit is important because, among other things, it reflects the detectability of the species, an issue that is further discussed below. Woody plants, readily detectable perennial species, account for $65(65 \%)$ of the listed taxa. The remainder are mostly far less easily detected, this is particularly so for the orchids because they flower for only a short period each year, if at all.

\section{Habitat}

The taxa listed occur in a wide range of habitats within the Region (Table 5). The greatest number of species, about $40 \%$, are found on sandstone landscapes, including forests, woodlands, heathlands and swamps. Even though the Region contains very extensive areas of forest habitat, this is not reflected in the number of threatened species found in forest. 


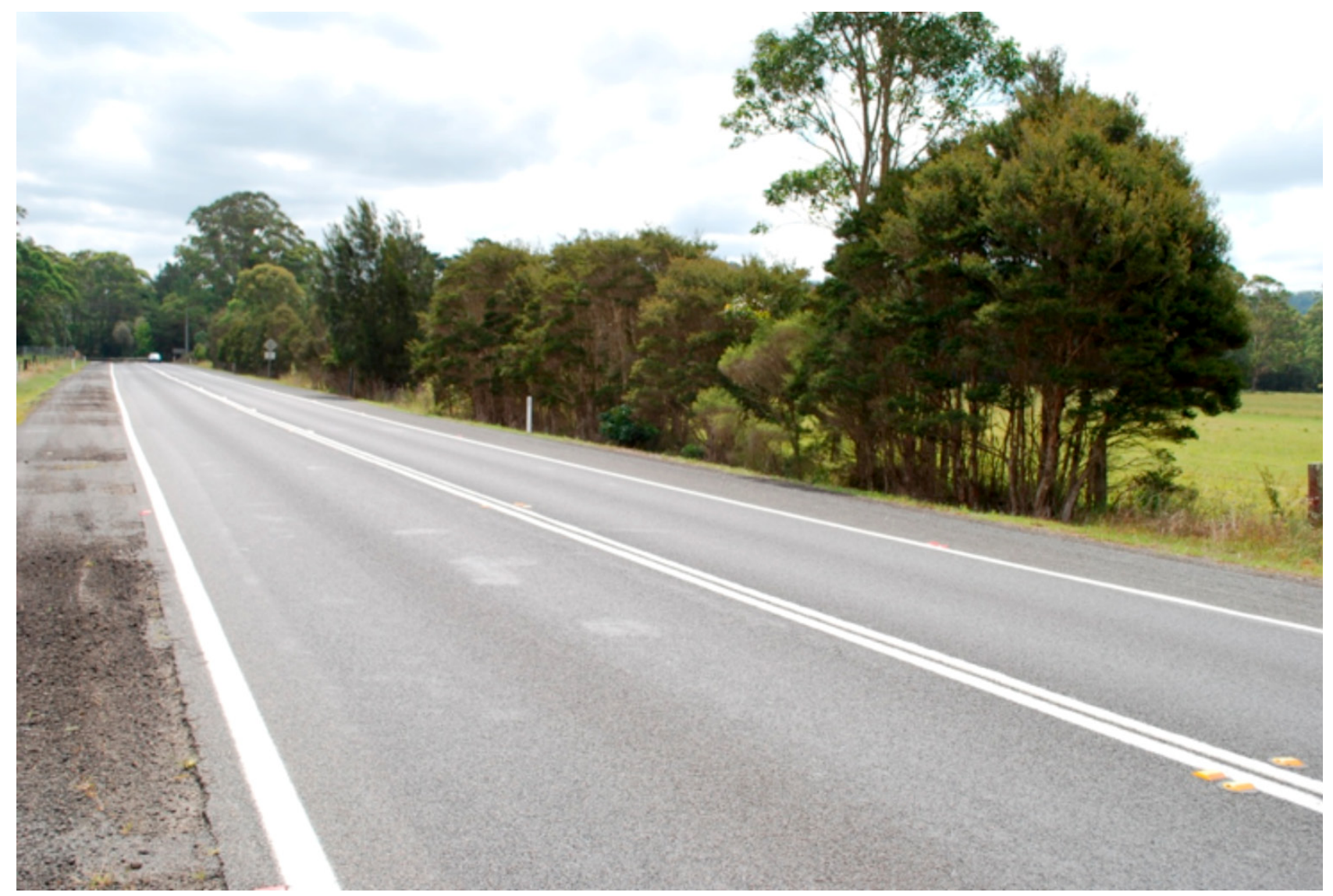

Fig. 1. The threatened tree Melaleuca biconvexa beside the Princes Highway at Wandandian. This species is not well represented within protected areas.

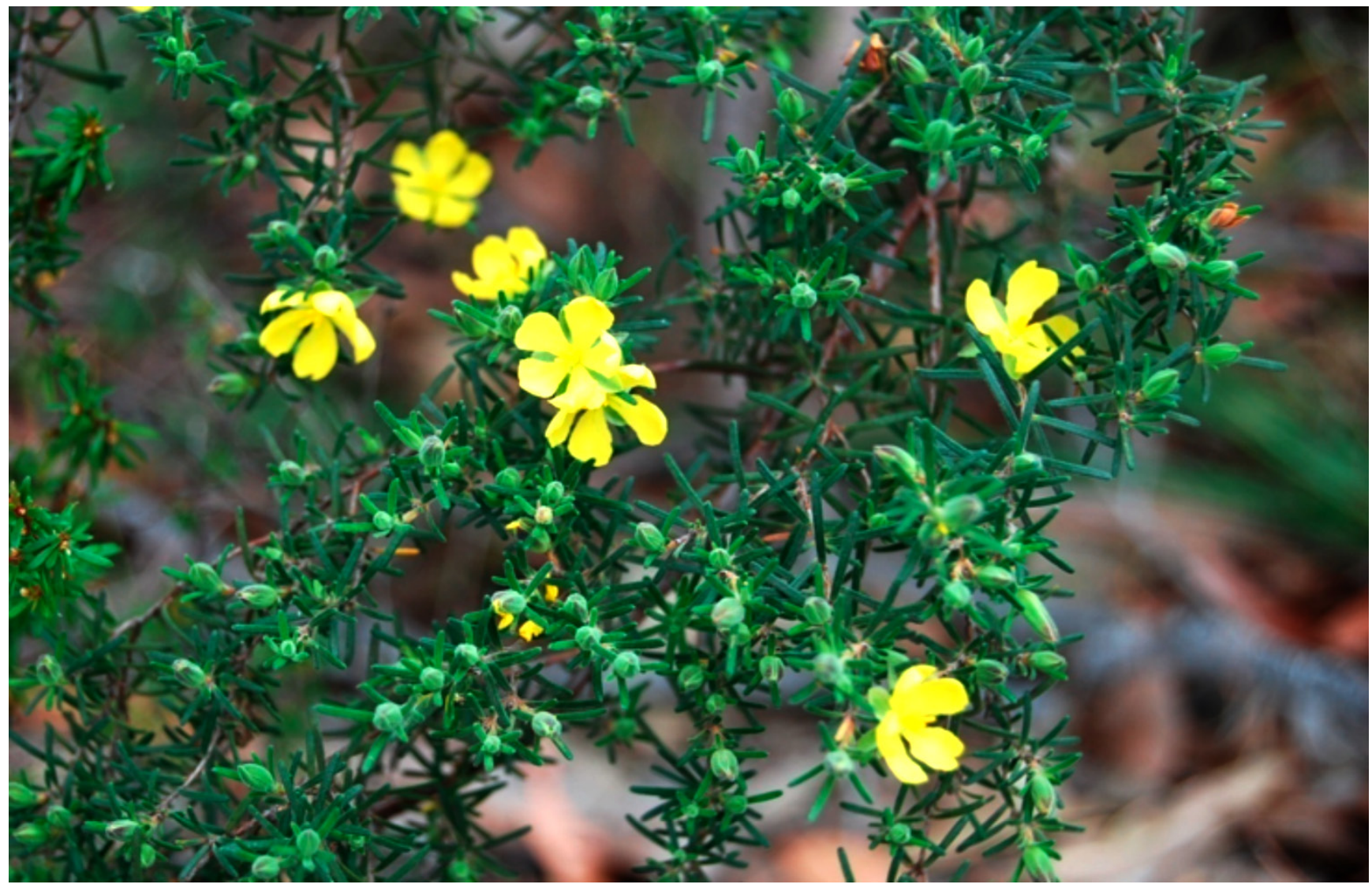

Fig. 2. Hibbertia stricta subsp. furcatula; recently found to be very common to the west of Nowra on the South Coast, particularly within Colymea SCA. 


\section{Adequacy of reservation}

Analysis of all 102 taxa indicates that 30 species are adequately reserved, 50 species are inadequate and adequacy for 22 species is unknown.

Among other things, the above figures indicate that much information is lacking in terms of our knowledge of the distribution and abundance of listed species. Although only an estimate, the fact that 50 percent of the listed taxa are identified as inadequately reserved is of concern. With such a high percentage of the land area of the region reserved, one may ask why this figure is so high. The answer is partly that the majority of inadequately reserved taxa occur in those areas where modified landscapes and private land dominates; i.e. in the coastal zone and on the tablelands. Lack of information on which species occur within which reserves is also a contributing factor. Most of the taxa associated with sandstone landscapes are considered to be adequately reserved.

\section{Conservation challenges}

The following regional examples demonstrate some of the challenges surrounding the conservation of threatened plants on the South Coast, and cover problems associated with surveying, reserving and managing listed taxa in the Region, as well as issues associated with rapidly changing information on individual species. The issues raised are by no means unique to this region.

\section{Difficulty of survey}

There are about 130 terrestrial orchids in the South Coast Region, including some undescribed taxa; 16 are currently listed as threatened. These plants flower once per year for a short period, if at all, and most cannot be confidently identified without flowers. Additionally, accurate identification of some taxa requires expert knowledge. For these reasons, assessing the potential impacts of developments or activities on listed orchids is particularly problematic. Habitat assessment can play an important role in such assessments (e.g. the work of Clark et al. 2004 on Cryptostylis hunteriana), but is not definitive. This is because of a lack of information on the preferred habitat, particularly for the rare species, and many species may occur in several habitats. Although the presence of orchid species in the Region is known, large sections of the reserve system and elsewhere remain inadequately surveyed for them. The known distribution and abundance of many species will ultimately change over the coming years; taxonomic revisions will also modify our view of this group in the Region.

Other small plants can often be difficult to locate in surveys. Galium australe, for example, is problematical, because it is small and easily overlooked, occurs in very scattered and small populations, and records of the taxon are often erroneous because of taxonomic confusion and misidentification.

\section{Difficulty of reservation}

Melaleuca biconvexa (Figure 1) is a tree growing in moist coastal places from Port Macquarie on the North Coast, south to Jervis Bay on the South Coast, where the species is quite localised, occurring from about Currambene Creek south to Wandandian, a distance of about 15 kilometres. Within that area populations are primarily found along drainage lines and on swampy ground, amongst developed land (almost entirely on private land), and very difficult to reserve within NPWS protected areas. Despite the key areas where it grows being on land zoned for environmental protection, or on large private holdings where development is unlikely, the species is threatened by infrastructure development and maintenance, pollution, weeds and clearing by land owners.

\section{Change in reservation status}

The reservation status of a species can change very quickly; this may occur as a result of inclusion within a newly gazetted protected area, or as a result of field surveys that record new populations within existing reserves.

The endemic mallee Eucalyptus langleyi occurs in a limited area to the west of Nowra, where there are 37 known populations containing many thousands of plants spread through the woodland and heathland on the Nowra Sandstone (Mills 2010). Prior to 2001 the species was unknown in a protected area, but a major dedication of Crown Land as conservation reserves in early 2001, particularly Colymea State Conservation Area, Parma Creek Nature Reserve and Jerrawangala National Park, protected nearly all known populations. Consequently the conservation status changed from highly inadequately reserved to almost completely reserved.

\section{Change in knowledge}

Information on the distribution of a species can change greatly through field survey; such is the case with Hibbertia stricta subsp. furcatula, (previously known as Hibbertia sp. nov. (Menai) (Figure 2). When the taxon was first listed in 2007 it was known from a few collections in Sutherland Shire on the southern outskirts of Sydney, and a handful of collections from near Nowra on the South Coast (NSW Scientific Committee 2007). At the time the Committee stated "the South Coast metapopulation is less well known [than the Sutherland metapopulation], but herbarium specimen records show it occurring just to the west and south-west of Nowra, with most of the six collections made prior to 1970."

Field studies by Mills (2009) found that this shrub is abundant within Colymea State Conservation Area, west of Nowra, and further searches by the author found populations in Bomaderry Creek Regional Park and Parma Creek Nature Reserve, near Nowra. The species must now be considered adequately reserved on the south coast. These findings also suggest that there is evidence that the taxon should be reclassified as vulnerable, rather than endangered. 


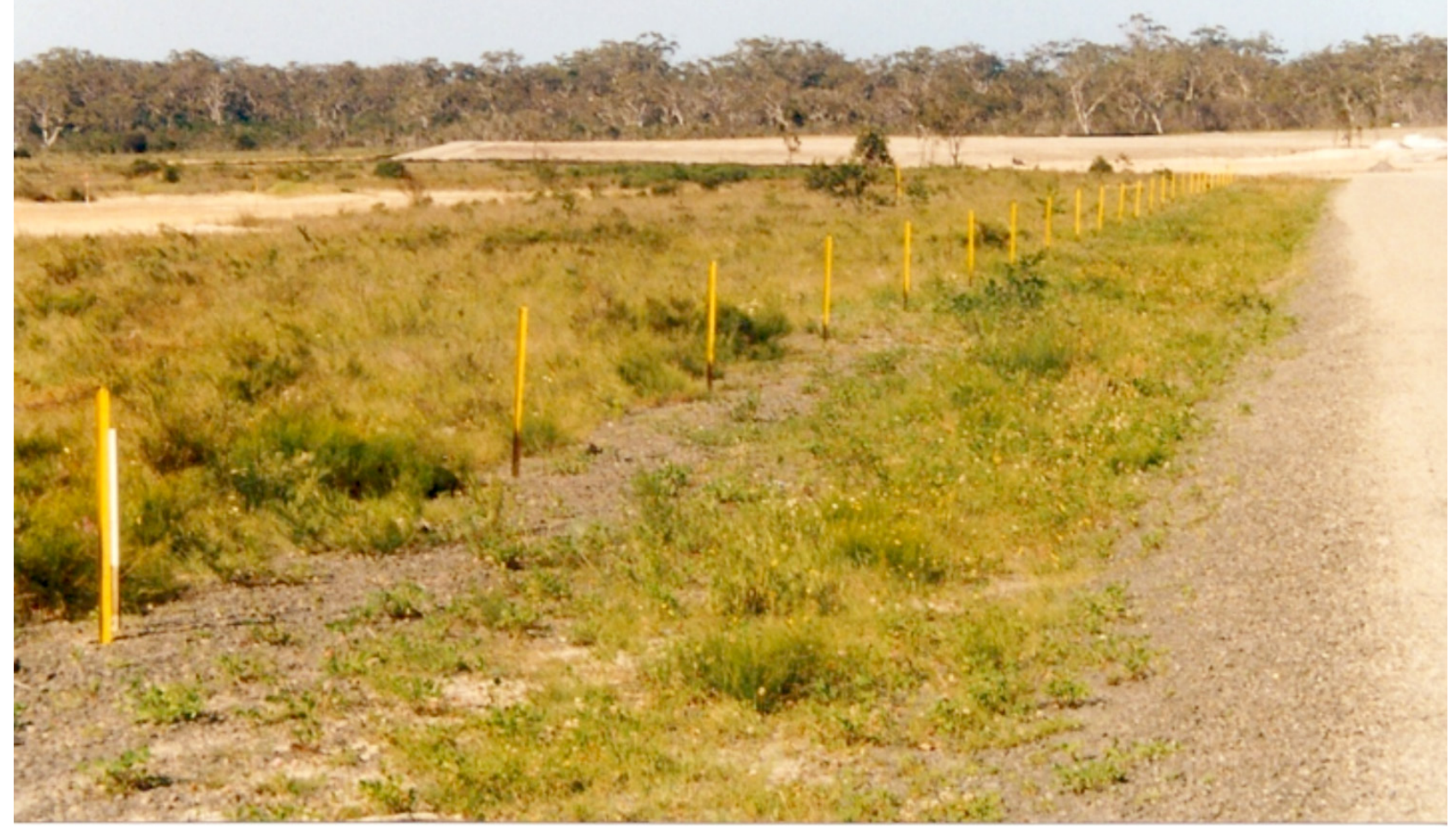

Fig. 3. Prasophyllum affine site at Vincentia in November 2000.

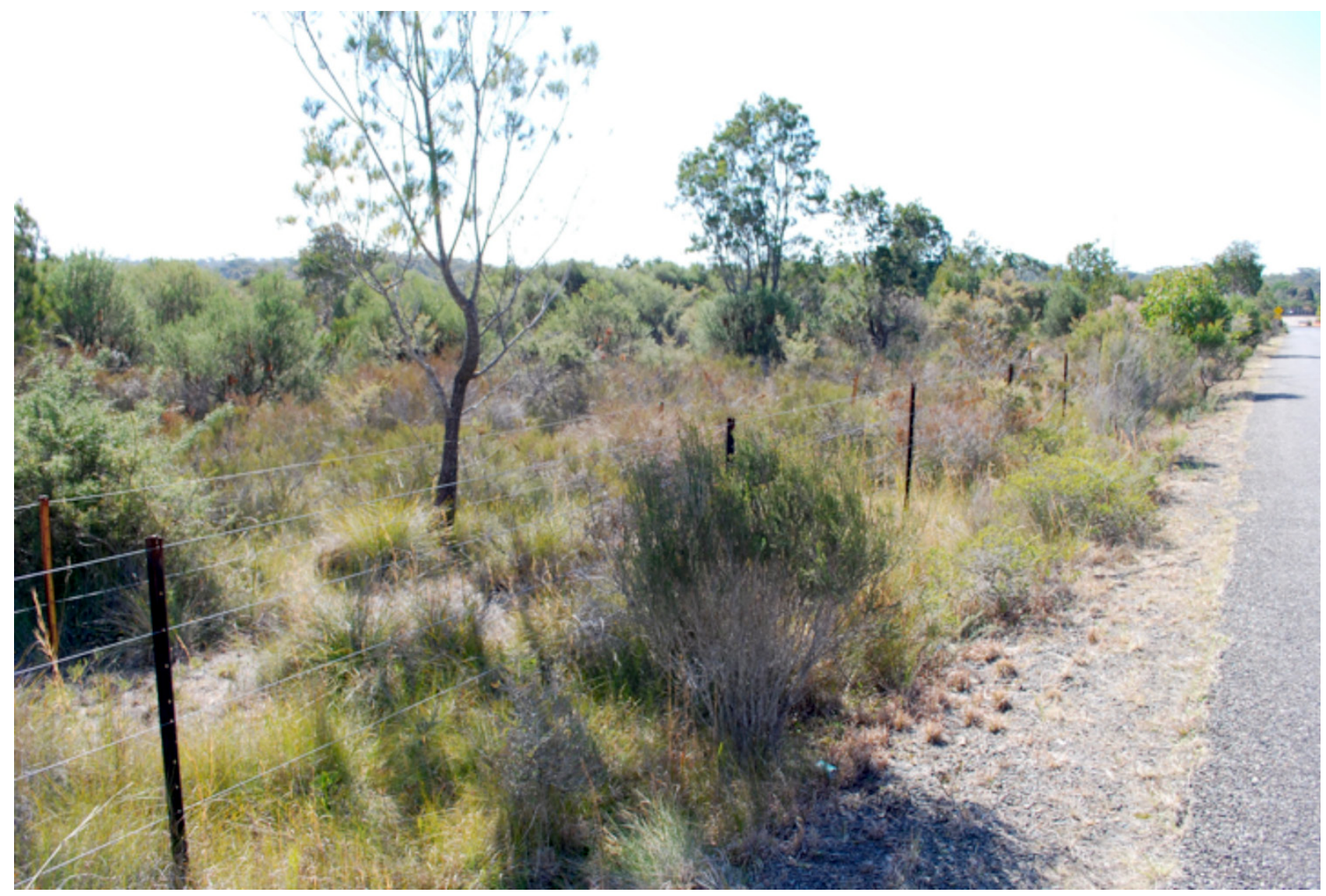

Fig. 4. Prasophyllum affine site at Vincentia in August 2012; taken from same location as in Figure 3. 
Table 4. Alphabetical list of protected areas in the NSW NPWS South Coast Region showing size and number of threatened species

1. To nearest hectare. 2. Species listed under the NSW Threatened Species Conservation Act 1995 and documented in Table 5. 3. CC - Central Coast; CT - Central Tablelands; SC - South Coast; ST - Southern Tablelands. 4. SB - Sydney Basin; SEC - South-East Corner; SEH - SouthEastern Highlands.

\begin{tabular}{|c|c|c|c|c|}
\hline NPWS Reserves & Area (hectares) ${ }^{1}$ & No. TSCA species ${ }^{2}$ & Botanical Subdivision $^{3}$ & Bio-Region $^{4}$ \\
\hline 1. Back Arm NR & 92 & 0 & $\mathrm{CT}$ & SEH \\
\hline 2. Bamarang NR & 374 & 1 & $\mathrm{SC}$ & SB \\
\hline 3. Bangadilly NP & 2137 & 1 & $\mathrm{CT}$ & SB \\
\hline 4. Barren Grounds NR & 2090 & 1 & $\mathrm{CT}$ & SB \\
\hline 5. Barrengarry NR & 21 & 0 & $\mathrm{SC}$ & $\mathrm{SB}$ \\
\hline 6. Bees Nest NR & 1541 & 1 & ST & SEH \\
\hline 7. Belowla Island NR & 3 & 0 & $\mathrm{SC}$ & SB \\
\hline 8. Berkeley NR & 9 & 2 & $\mathrm{CC}$ & $\mathrm{SB}$ \\
\hline 9. Bimberamala National Park & 4420 & 0 & $\mathrm{SC}$ & SEC \\
\hline 10. Bomaderry Creek Regional Park & 85 & 4 & $\mathrm{CC}$ & SB \\
\hline 11. Brundee Swamp NR & 227 & 0 & $\mathrm{SC}$ & SB \\
\hline 12. Brush Island NR & 37 & 0 & SC & SB \\
\hline 13. Budawang NP & 23819 & 5 & ST & SEH.SB \\
\hline 14. Budderoo NP & 7217 & 12 & $\mathrm{CT}$ & SB \\
\hline 15. Bugong NP & 1011 & 0 & $\mathrm{CC}$ & SB \\
\hline 16. Bungonia NP & 770 & 3 & ST & SEH \\
\hline 17. Bungonia State Conservation Area & 3285 & 4 & ST & SEH \\
\hline 18. Cambewarra Range NR & 1681 & 4 & $\mathrm{CC}$ & SB \\
\hline 19. Cecil Hoskins NR & 47 & 1 & $\mathrm{CT}$ & SB \\
\hline 20. Clyde River NP & 1263 & 0 & SC & SEC \\
\hline 21. Colymea SCA & 1674 & 5 & $\mathrm{SC}$ & SB \\
\hline 22. Comerong Island NR & 714 & 0 & SC & SB \\
\hline 23. Conjola NP & 11599 & 5 & SC & SB \\
\hline 24. Cookbundoon NR & 539 & 0 & ST & SEH \\
\hline 25. Corramy RP & 291 & 1 & $\mathrm{SC}$ & SB \\
\hline 26. Cullendulla Creek NR & 127 & 0 & $\mathrm{SC}$ & SEC \\
\hline 27. Cullunghutti AA & 66 & 0 & $\mathrm{CC}$ & SB \\
\hline 28. Dharawal NR & 376 & 1 & $\mathrm{CC}$ & SB \\
\hline 29. Dharawal SCA & 6685 & 6 & $\mathrm{CC}$ & SB \\
\hline 30. Five Islands NR & 278 & 0 & $\mathrm{CC}$ & SB \\
\hline 31. Illawarra Escarpment SCA & 2635 & 5 & $\mathrm{CC}$ & $\mathrm{SB}$ \\
\hline 32. Jerralong NR & 334 & 0 & ST & SEH \\
\hline 33. Jerrawangala NP & 4031 & 4 & SC & SB \\
\hline 34. Jervis Bay NP & 5248 & 9 & $\mathrm{SC}$ & SB \\
\hline 35. Kangaroo River NR & 118 & 0 & $\mathrm{CC}$ & SB \\
\hline 36. Kerrawary NR & 366 & 0 & ST & SEH \\
\hline 37. Macquarie Pass NP & 1062 & 2 & $\mathrm{CC}$ & SB \\
\hline 38. Macquarie Pass SCA & 166 & 0 & $\mathrm{CC}$ & SB \\
\hline 39. Meroo NP & 3846 & 3 & SC & SB \\
\hline 40. Morton NP & 199744 & 32 & SC.CT.ST & SB. SEH \\
\hline 41. Morton SCA & 1028 & 0 & $\mathrm{SC}$ & SB \\
\hline 42. Murramarang Aboriginal Area & 60 & 0 & $\mathrm{SC}$ & SB \\
\hline 43. Murramarang NP & 12367 & 3 & SC & $\mathrm{SB}$ \\
\hline 44. Nadgigomar NR & 3868 & 4 & ST & SEH \\
\hline 45. Narrangarril NR & 105 & 0 & ST & SEH \\
\hline 46. Narrawallee Creek NR & 872 & 0 & $\mathrm{SC}$ & $\mathrm{SB}$ \\
\hline 47. Parma Creek NR & 3643 & 2 & $\mathrm{SC}$ & SB \\
\hline 48. Pomaderris NR & 100 & 1 & ST & SEH \\
\hline 49. Robertson NR & 5 & 0 & $\mathrm{CT}$ & SB \\
\hline 50. Rodway NR & 85 & 0 & $\mathrm{SC}$ & SB \\
\hline 51. Saltwater Swamp NR & 214 & 0 & $\mathrm{SC}$ & SB \\
\hline 52. Seven Mile Beach NP & 953 & 1 & $\mathrm{CC}$ & SB \\
\hline 53. Tapitallee NR & 94 & 0 & $\mathrm{CC}$ & $\mathrm{SB}$ \\
\hline 54. Tarlo River NP & 8211 & 3 & ST & SEH \\
\hline 55. Tollgate Islands NR & 11 & 0 & $\mathrm{SC}$ & SEC \\
\hline 56. Triplarina NR & 151 & 3 & $\mathrm{CC}$ & SB \\
\hline 57. Upper Nepean SCA & 25268 & 7 & $\mathrm{CC}$ & SB \\
\hline 58. Wogamia NR & 278 & 0 & $\mathrm{SC}$ & SB \\
\hline 59. Woollamia NR & 453 & 1 & SC & SB \\
\hline 60. Worrigee NR & 615 & 1 & SC & SB \\
\hline 61. Yatteyattah NR & 35 & 0 & SC & SB \\
\hline Region total reserved NPWS land & 348,193 ha & & & \\
\hline \multicolumn{5}{|c|}{ Parks Australia Reserve (Jervis Bay Territory) } \\
\hline 62. Booderee National Park & 6,312 ha & 1 & $\mathrm{SC}$ & SB \\
\hline
\end{tabular}




\section{Unexpected Discoveries}

Much of the Region is botanically under-explored, at least in terms of its detail, and botanical forays into the wilderness areas regularly turn up unexpected finds. Two such finds were recently made by the author in the sandstone country west of Nowra, neither of which were very far from public access tracks. The shrub Hakea dohertyi was previously known only from a small area in the Blue Mountains, until it was found in the Shoalhaven about $77 \mathrm{~km}$ further south, in a different botanical subdivision (Mills 2008). The question arose as to whether the occurrence was natural or whether seeds had been transported from the Blue Mountains to the South Coast site by a 4WD vehicle.

The shrub Zieria murphyi occurs on the Central Tablelands, in the Blue Mountains and in the Penrose-Bundanoon area. The author came across populations of this species on the South Coast about $50 \mathrm{~km}$ south of the closest known occurrence at Penrose. There is no doubt that many other such discoveries are yet to be made in the remote and not so remote parts of the region. Every new discovery modifies and enhances our knowledge of the threatened species in the Region.

\section{Species in highly modified environments}

The problem of conserving rare species in highly modified environments in not new. The major reason for species decline in these areas is habitat loss and disturbance, along with competition from weeds; such species may not have originally been rare. Several species associated with the Permian volcanics in the Shellharbour - Kiama area have suffered greatly from the extensive clearing of the subtropical rainforest and associated vegetation in that district; these species include Zieria granulata, Daphnandra johnsonii and Cynanchum elegans. These species are now restricted to remnants and regrowth vegetation across their former limited range; occurrences are largely on private land. The first two species are endemic to the region and are of high priority for conservation efforts but reserving the habitat of these species is very difficult because of the highly fragmented nature of the remnants.

\section{Manipulating habitat for threatened species}

Plant populations are not stable over time, as habitat change in response to environmental conditions, fire, geomorphic influences and growth of vegetation is inevitable. Habitat change may be beneficial to some species but detrimental to others. Generally, disturbance will be beneficial to shortlived "pioneer" species, while being detrimental to long-lived species. Fire is the omnipotent force in Australian vegetation dynamics and may be a key determinant of vegetation structure and species composition; fire ecology is a large subject on its own and will not be further discussed here.

Habitat manipulation is sometimes necessary to maintain a population of a rare species. For example the orchid Prasophyllum affine is endemic to the Jervis Bay district and is known only from a handful of discrete sites. The largest population is at Vincentia, where the natural habitat is sedge-heathland. Since the population was discovered in 2000, shrubs and trees have invaded the area such that within a short time the whole area will support dense woody vegetation; see Figures 3 and 4. This terrestrial orchid is unlikely to tolerate a dense shrub cover so is likely to be lost from the site unless the woody plants are removed. Because of surrounding developments, wildfire is now unlikely so that intervention to modify the habitat, i.e. to remove shrub and tree cover, is required to manage the site for the orchid's survival.

\section{Unnatural occurrences}

The tree Syzygium paniculatum grows primarily in littoral rainforest; it occurs north from Lake Conjola on the South Coast to Bulahdelah on the North Coast. This is now a commonly grown garden plant and has been planted extensively within its natural range and well outside of it along the coast. Where specimens are found in its usual natural coastal habitat the question arises whether it is a natural population or whether it has originated from a planted tree in the vicinity of the occurrence. If originating from planted specimens, what is its conservation value? Does it have the same legal protection as a natural occurrence? The dilemma of planted individuals of threatened species is not addressed in the Final Determination from the NSW Scientific Committee listing this species, nor is it addressed for any other listed species that is used in cultivation. There is a concern about maintaining the genetic integrity of natural populations when specimens of unknown origin are planted nearby and may interbreed.

\section{Discussion}

The listed threatened species occurring in the South Coast Region encompass a broad range of species in terms of growth habit, distribution, rarity and reservation status. The majority of the Region still supports natural vegetation so that some of the listed species are identified as threatened because they are naturally rare or have a highly restricted geographic distribution, rather than becoming threatened through habitat removal or other human activity; about 14 percent of the taxa are in this category. The conservation of most of the listed species relies upon appropriate management of the reserve system and other public land, including state forests, Crown land and council land.

The most important taxa in the Region are the endemic species, as they occur nowhere else in the wild. Of the 34 endemic/near endemic species, $12(35 \%)$ are considered to be adequately reserved, while $20(59 \%)$ are considered inadequately reserved. Possibly the most important is the endemic monotypic genus Budawangia (Ericaceae), a genus of only one species Budawangia gnidioides, almost entirely confined to Morton National Park (it is named from the Budawang Range), and is adequately reserved.

The priority for conservation effort should be directed towards those endemic taxa that occur outside the reserve system, particularly those occurring in highly modified environments 


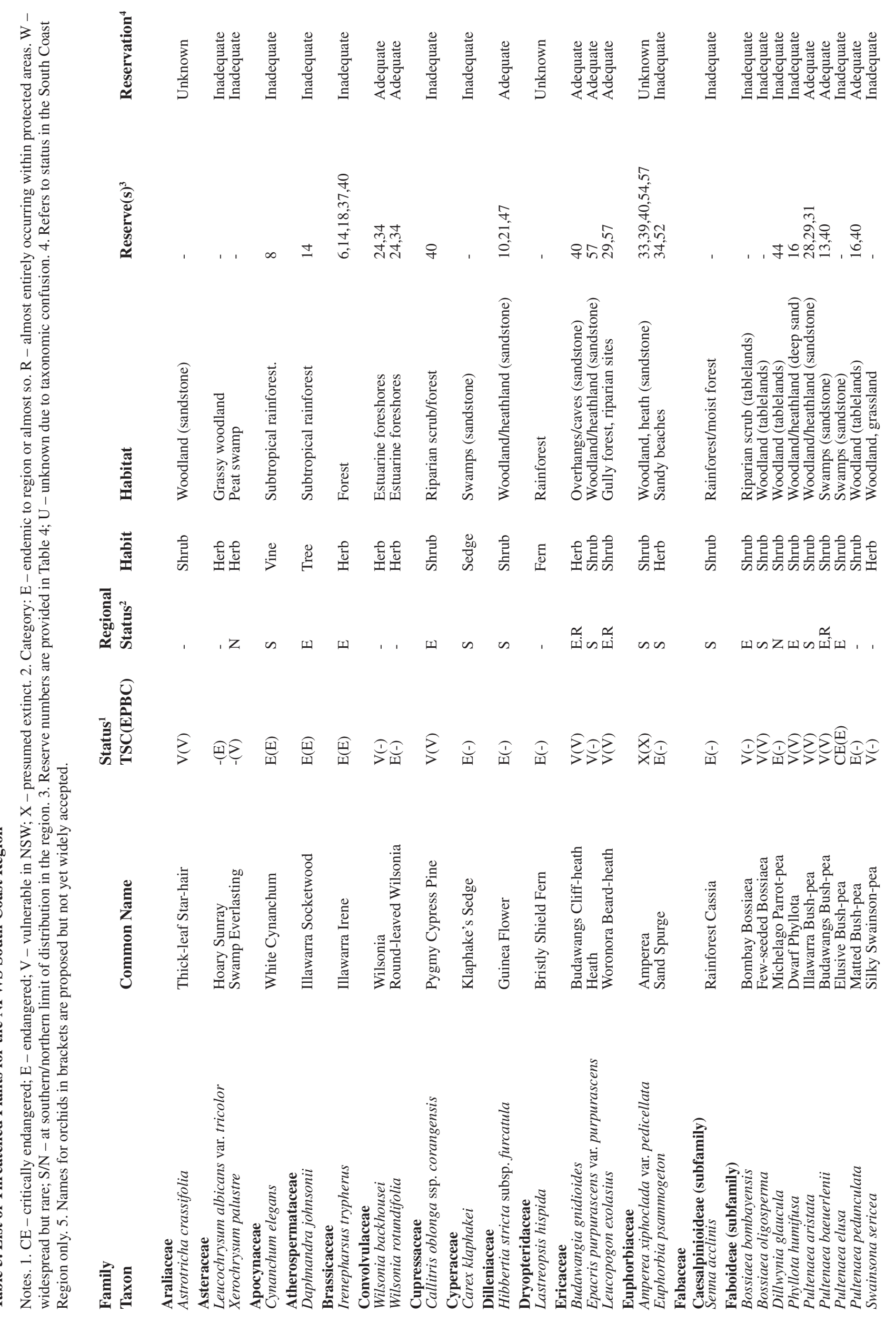


菊

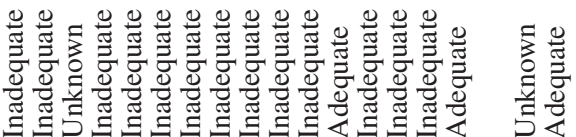

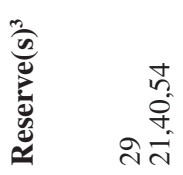

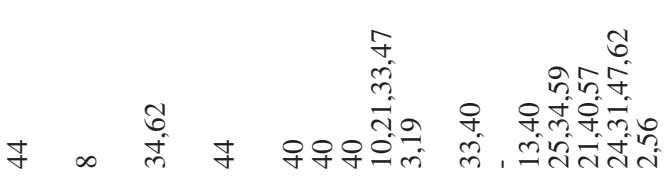

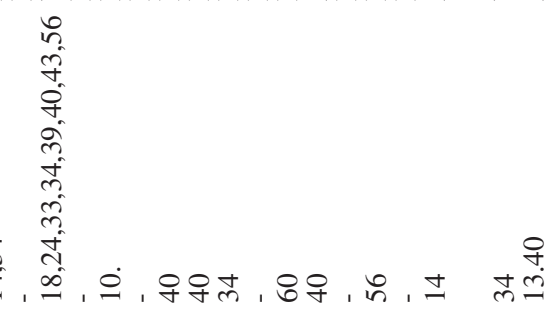

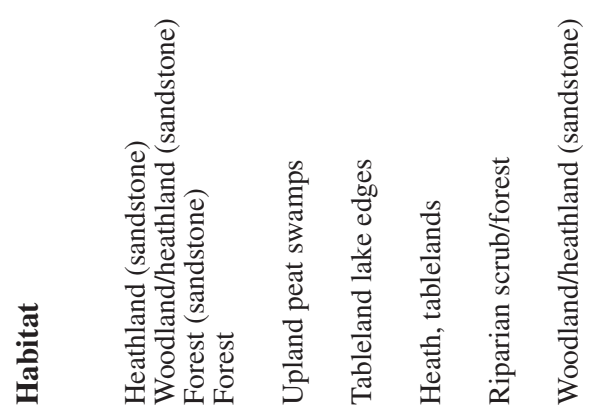
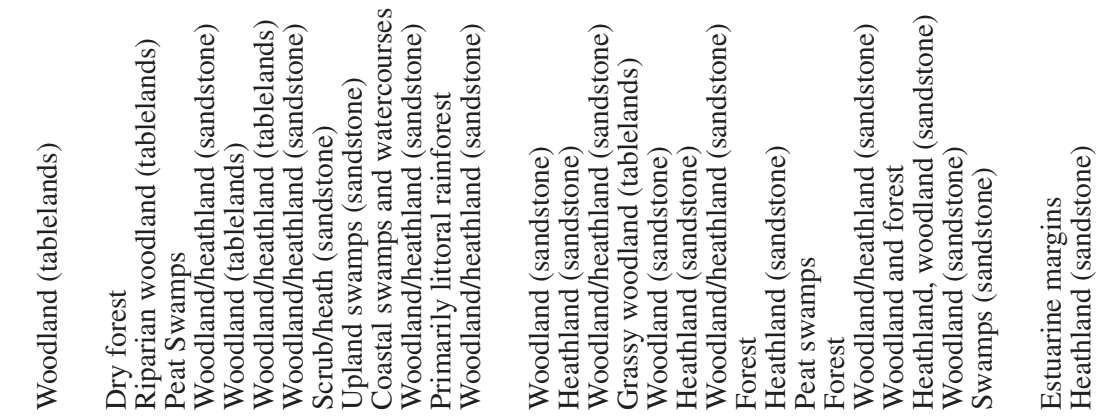

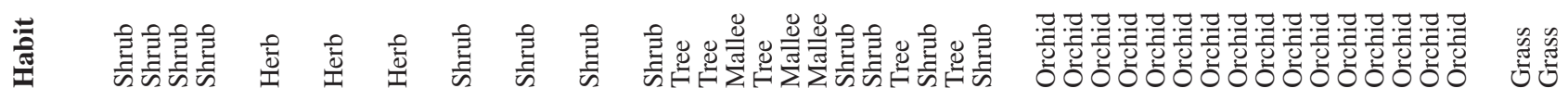

高

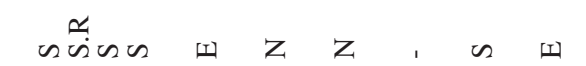

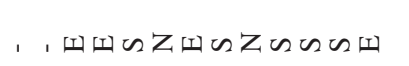

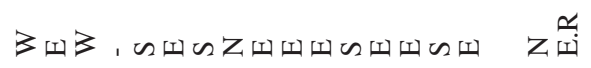

氙

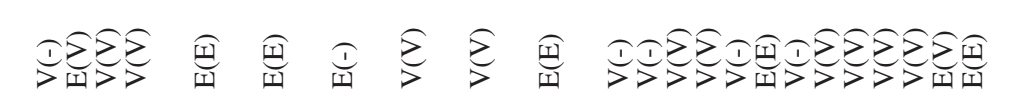

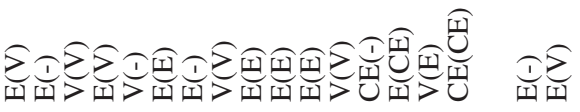

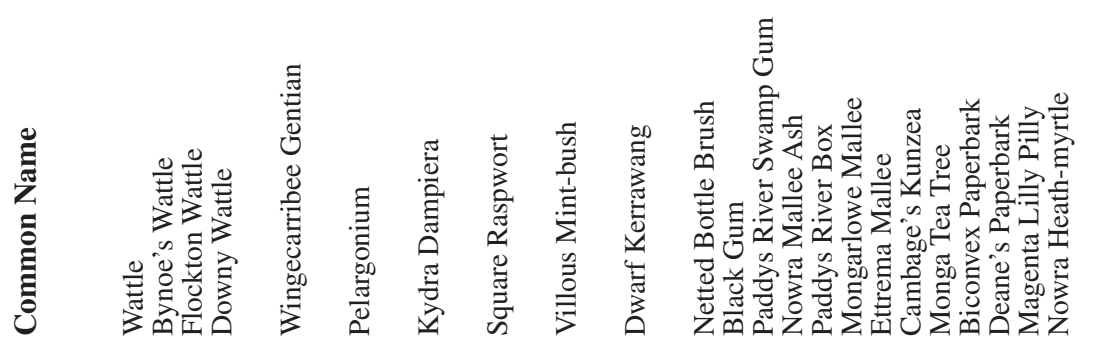

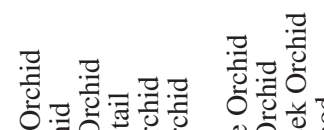

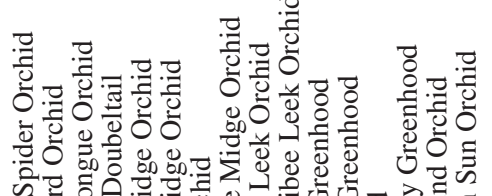

ñ

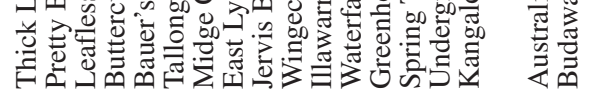

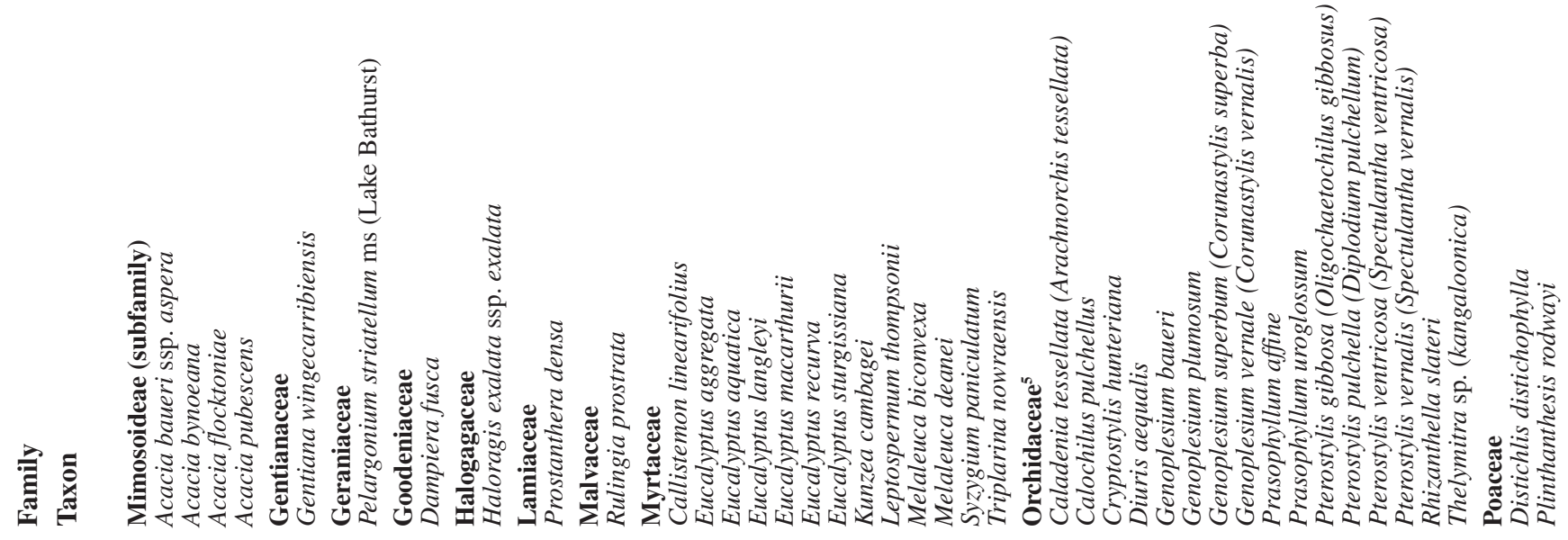




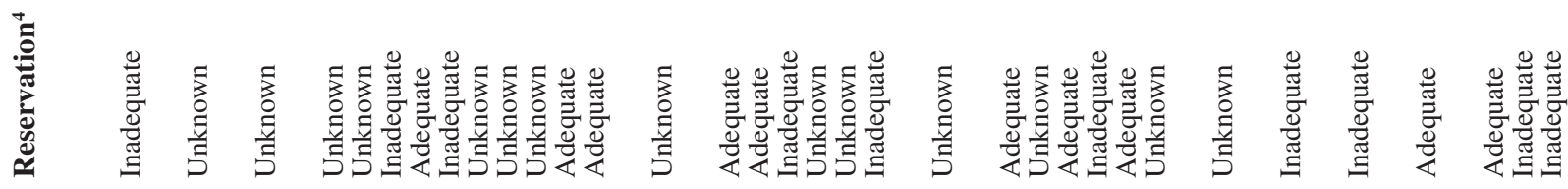

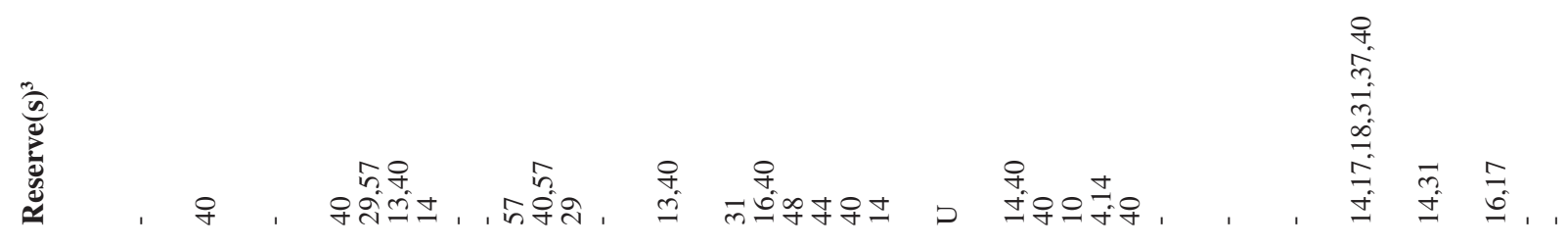

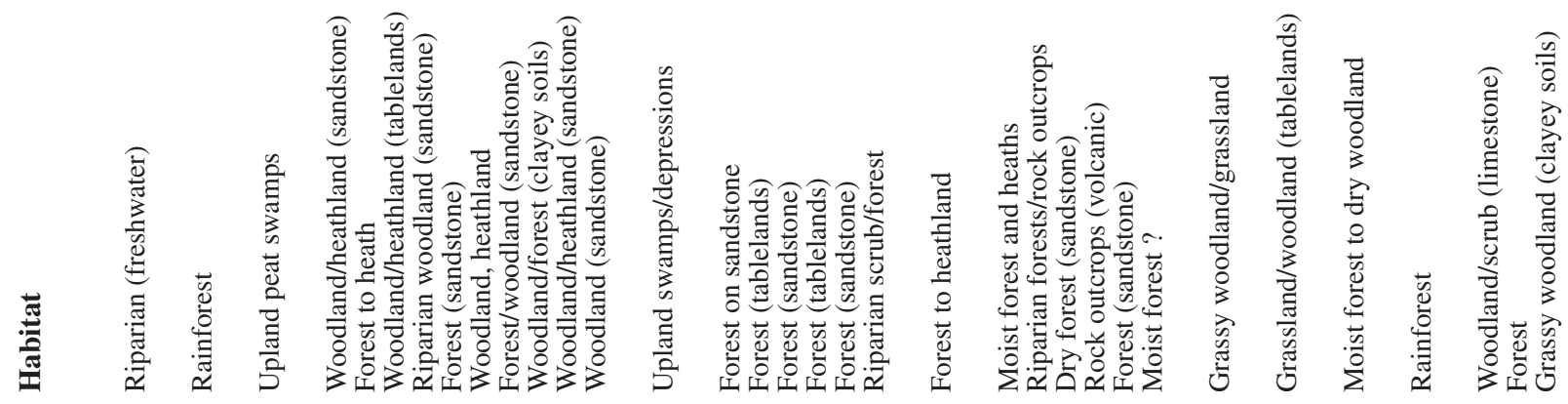

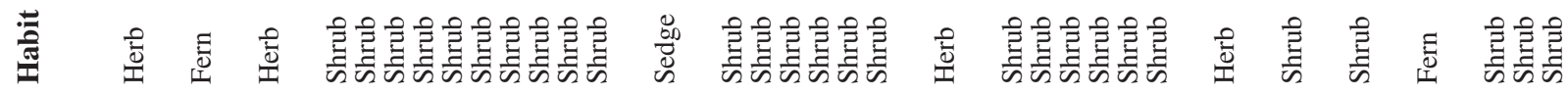

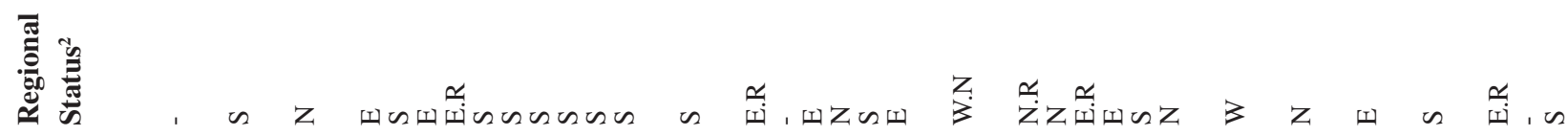

管竞

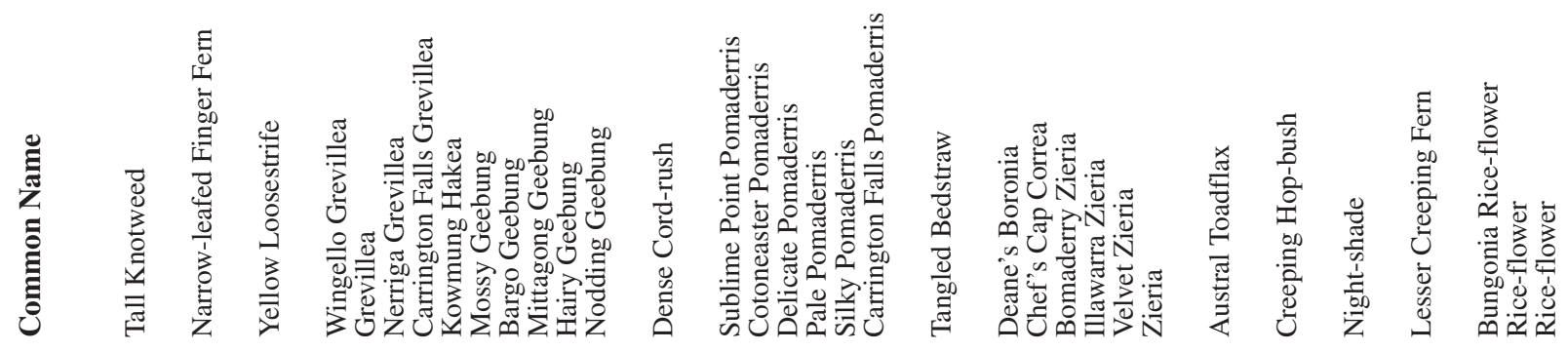

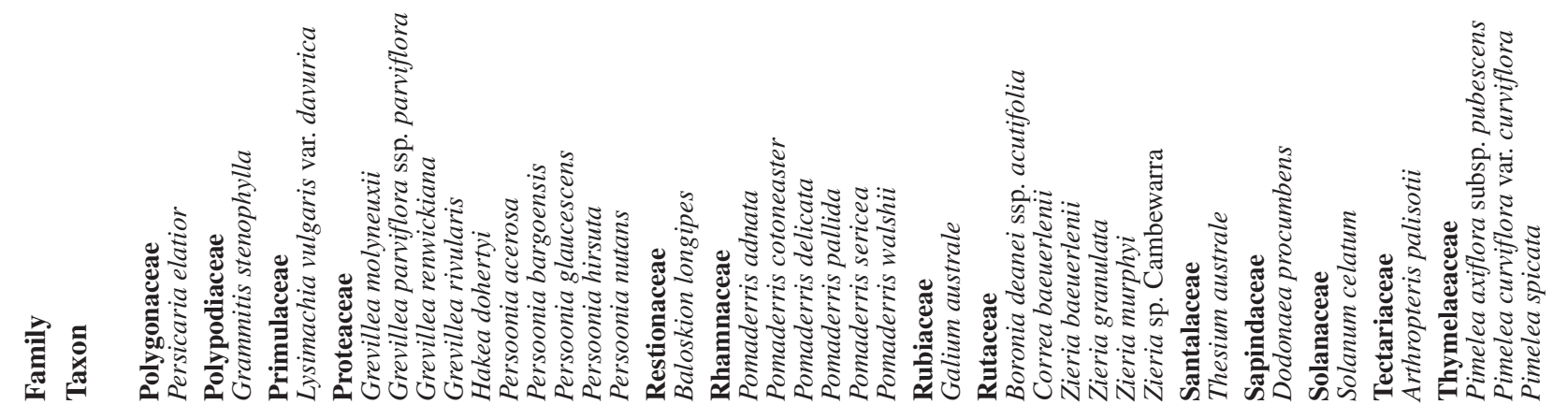


or areas with current or likely future development pressure. Three areas that stand out in this regard are:

i) the Permian volcanics in the far northeast of the region, which include the endemics, Cynanchum elegans and Zieria granulata;

ii) the Nowra-Jervis Bay area, which has a high concentration of endemic species for example Prasophyllum affine and Zieria baeuerlenii, and is under much development pressure;

iii) the tablelands, where there are few reserves and listed species are widely dispersed across an often highly modified landscape, for example Diuris aequalis and Eucalyptus aggregata.

The reservation status of individual taxa varies from those that are wholly within the reserve system to those that are not represented in any reserve. Based on current knowledge, and some reasonable assumptions, only $30 \%$ of the listed taxa are considered to be adequately reserved. Most of these occur on sandstone landscapes, where most of the reserves are located.

Adequately reserved does not always mean that a species is secure; reserve management is often critical to ensure long term viability. Fire management can manipulate habitat but there may be a balance between individual species needs (plants and animals) and the need for protection of humans and their assets. Activities within reserves, such as provision of visitor facilities and road maintenance may be detrimental to some species. Lack of ecological information on a species and its habitat, and the location of the species in the reserve are often problems in this regard.

Not surprisingly, there is a general positive relationship between reserve size and the number of listed taxa in the reserve, that is the larger the reserve the more taxa present. But the pattern is more complicated than this, and there do seem to be concentrations of listed species in certain districts (as noted above) so that reserves in those localities contain higher numbers of taxa. Small reserves can also contain a higher number of taxa than may be expected, while the extensive Budawang National Park contains fewer species than would perhaps be expected.

Some listed species occur on public land other than NPWS estate. These lands are not reserved for conservation as their primary purpose, nor are they subject to formal management regimes developed to conserve natural conservation values. However this is not to dismiss such land as unimportant for the conservation of threatened plants; many areas, including some small council reserves, contribute importantly to regional conservation efforts.

Managing highly localised taxa, whether in a reserve or not, poses a challenge as individual incidents can destroy or seriously deplete a population. This is nowhere more evident than in the case of orchids, where many of the listed species have very localised occurrences. A single development such as a road upgrade could potentially destroy most of the known population of very restricted species.

Recognition of the ecological requirements of individual taxa is also an important consideration for the land manager. As with the example of Prasophyllum affine above, not doing something may be just as detrimental as carrying out an activity. Other species, such as Plinthanthesis rodwayi, a grass endemic to the Budawang Ranges, and Thesium australe, a grassland species on the coast and tablelands, may also be negatively impacted by lack of disturbance and increasing shrub density. Disturbance is beneficial to some species; such disturbance may come from fire, natural geomorphic change or even unnatural modifications to vegetation and/or soil.

Managing highly dispersed small populations of a taxon, particularly within a highly modified landscape, is particularly problematic. The vine Cynanchum elegans grows in subtropical rainforest remnants and associated Lantana thickets in the largely cleared landscape between Wollongong and Kiama. Individual plants are usually found, separated by kilometres of grazing paddocks and developed land. Reservation of sites in such circumstances is difficult and the species is threatened by clearing of regrowth and Lantana, both able to be legally carried out as a routine agricultural practice. The long term viability of such small and isolated populations must be of concern.

This paper has dealt only with those taxa specifically listed under Commonwealth and State threatened species legislation. There are also nationally listed rare species, usually referred to as ROTAP species (Briggs \& Leigh 1996), that warrant consideration in plant species conservation. The ROTAP list has no legislative significance and is dated, but is still useful in identifying those species considered to be rare. Although most of these are likely to be adequately reserved, climate change, development pressure and/or further field study may well see some of these species listed as threatened in the future.

\section{Conclusion}

This paper has presented the current situation for listed threatened plants in the South Coast Region; it must be regarded as a "snapshot in time". Further field studies will result in new listings of plants, and future new reservations of land for conservation purposes, albeit small in area, will inevitably occur. Other investigations will modify our understanding of the distribution and abundance of some species, including reservation status; various taxonomic changes will also occur.

Several key challenges for the conservation of threatened plants in the Region have been identified. Managing for individual plant species may be hampered by a lack of basic ecological information; this is particularly so for the rarer species such as orchids. One of the main areas where information is lacking is the response of most species to bushfire. 
Conservation on private land is becoming an increasingly important and challenging area for plant species conservation as the last large areas of public land are dedicated for one purpose or another. Mechanisms are available for conservation on private land, including voluntary conservation agreements, and assistance through the Landrace program and catchment management authorities. A more co-ordinated approach to conservation on private land may produce improved outcomes for many inadequately reserved taxa.

Climate change and sea level rise are unknown challenges ahead. The tendency towards a more severe fire regime, i.e. more frequent and hotter fires, may pose the greatest threat to plant conservation. The predicted rise in sea level will affect beaches and estuaries; some of this change will be unpredictable, but a changing coastal environment is more likely than not.

\section{Acknowledgements}

Phil Craven, NPWS Nowra office, Doug Benson of the Royal Botanic Gardens and Domain Trust, and an anonymous reviewer made useful comments on drafts of the paper.

\section{References}

Commonwealth of Australia (1999). Environment Protection and Biodiversity Conservation Act 1999. Commonwealth Government, Canberra.

Briggs, J. \& Leigh, J. (1996). Rare or Threatened Australian Plants. CSIRO, Canberra, 466pp.

Clark, S., deLacey, C. \& Chamberlain, A. (2004). Using environmental variables and multivariate analysis to delineate preferred habitat for Cryptostylis hunteriana, the Leafless Tongue Orchid, in the Shoalhaven Local Government Area, NSW. Cunninghamia 8(4); 467-476.

Mills, K. (2006). The beach flora of the South Coast Region of New South Wales. Illawarra Vegetation Studies, 15. Coachwood Publishing, Jamberoo, April.

Mills, K. (2009). Investigation of the undescribed taxon Hibbertia sp. nov. 'Menai' (Dilleniaceae). Kevin Mills \& Associates, Jamberoo, December.

Mills, K. (2008). Rare Plants of the Illawarra 3: The Endangered Shrub Hakea dohertyi (Proteaceae) in the Shoalhaven Region. Illawarra Vegetation Studies (17), Coachwood Publishing, Jamberoo, NSW, December.

Mills, K. (2010). Rare Plant Species in the Illawarra 4: Eucalyptus langleyi (Myrtaceae). Illawarra Vegetation Studies (20), Coachwood Publishing, Jamberoo, NSW.

Mills, K. \& Jakeman, J. (2010). Native Trees of the NSW South Coast. Envirobooks, Canterbury, 246pp.

National Parks and Wildlife Service (NPWS) (2003). The Bioregions of New South Wales: their biodiversity, conservation and history. NSW National Parks and Wildlife Service, Hurstville.

New South Wales (1995). Threatened Species Conservation Act 1995. NSW Government, Sydney.

New South Wales (1994). Fisheries Management Act 1994. NSW Government, Sydney.

NSW Scientific Committee (2007). Final Determination: Hibbertia $s p$. nov. 'Menai' as an endangered species. The Committee, Hurstville, August.

Stephenson, A. W. (2011). Orchid Species of the Shoalhaven. The Author, Nowra, 54 pp.

Manuscript accepted 19 October 2012 
